\title{
Pengaruh Penerapan Metode Visualization, Auditory, Kinestetic (VAK) Terhadap Hasil Belajar Fiqih Materi Tatacara Pengurusan Jenazah
}

\author{
Hasanudin $^{1 *}$ dan Mu'arif ${ }^{2 \star}$ \\ ${ }^{1}$ STKIP Nurul Huda OKU Timur \\ ${ }^{2}$ Dosen STKIP Nurul Huda OKU Timur \\ *E-mail: hasanudin@gmail.com \\ *E-mail: muarif@gmail.com
}

\begin{abstract}
Abstrak
Penelitian ini dilatarbelakangi kurang efektifnya pembelajaran Fiqih di kelas X MA Nurul Huda Sukaraja. Tujuan penelitian ini adalah untuk mengetahui pengaruh penerapan metode Visualization, Auditory, Kinestetic (VAK) terhadap hasil belajar Fiqih materi Tatacara Pengurusan Jenazah peserta didik kelas X MA Nurul Huda Sukaraja. Dilihat tingkat eksplanasi termasuk jenis penelitian eksperimen menggunakan desain quasi eksperiment. Sampel penelitian ini adalah seluruh peserta didik kelas X IPA dan X MAK MA Nurul Huda Sukaraja yang berjumlah 56 peserta didik. Teknik pengumpulan data menggunakan tes dan dokumentasi sedangkan uji hipotesis dilakukan menggunakan uji $t$ polled varian. Sebagai kegiatan akhir analisis data penelitian dapatlah disimpulkan Pertama: Hasil I belajar Fiqih materi Tatacara Pengurusan Jenazah peserta didik yang pembelajarannya menerapkan metode Visualization, Auditory, Kinestetic (VAK) di kelas X MA Nurul Huda Sukaraja Kecamatan Buay Madang adalah sedang. Kedua: Hasil belajar Fiqih materi Tatacara Pengurusan Jenazah peserta didik yang pembelajarannya menerapkan metode ceramah di kelas X MA Nurul Huda Sukaraja Kecamatan Buay Madang adalah sedang. Ketiga: Terdapat pengaruh yang signifikan penerapan metode Visualization, Auditory, Kinestetic (VAK) terhadap hasil belajar Fiqih materi Tatacara Pengurusan Jenazah peserta didik kelas X MA Nurul Huda Sukaraja Kecamatan Buay Madang.
\end{abstract}

Kata kunci: Metode Visualization, Auditory, Kinestetic, Hasil Belajar Fiqih

\section{PENDAHULUAN}

Mata Pelajaran Fiqih dalam kurikulum Madrasah Aliyah adalah bagian dari mata pelajaran Pendidikan Agama Islam yang diarahkan untuk menyiapkan peserta didik untuk mengenal, memahami, menghayati dan mengamalkan hukum Islam yang kemudian menjadi dasar pandangan hidup melalui kegiatan bimbingan, pengajaran, latihan, penggunaan pengalaman, pembiasaan dan keteladanan. Kurikulum 2013 untuk mata pelajaran Fiqih menyebutkan bahwa tujuan pembelajaran Fiqih di Madrasah Aliyah adalah untuk membekali peserta didik agar dapat mengetahui dan memahami pokok-pokok hukum Islam secara terperinci dan menyeluruh, baik berupa dalil naqli dan aqli. Selain itu, pembelajaran Fiqih ditujukan agar peserta didik dapat melaksanakan dan mengamalkan ketentuan hukum Islam dengan benar (Kemendikbud, 2016:2).

Mata pelajaran Fiqih menjadi salah satu mata pelajaran Pendidikan Agama Islam yang diberikan diberbagai lembaga pendidikan Islam seperti di Madrasah Aliyah (MA) Nurul Huda Sukaraja Kecamatan Buay Madang Kabupaten OKU Timur. Pembelajaran Fiqih di MA Nurul Huda Sukaraja dilaksanakan berdasarkan Kurikulum 2013 edisi revisi 2016 untuk kelas X dan kelas XI, sedangkan untuk kelas XII masih diberlakukan kurikulum tingkat satuan pendidikan. Pembelajaran Fiqih di MA Nurul Huda Sukaraja diarahkan untuk memberikan bekal pengetahuan sekaligus pengalaman langsung peserta didik terhadap materi-materi hukum Islam.

Secara umum pembelajaran Fiqih di MA Nurul Huda Sukaraja telah berjalan dengan baik. Berdasarkan hasil pengamatan peneliti selama dua bulan yaitu pada bulan September sampai bulan November 2017 diketahui bahwa sebagian pendidik di MA Nurul Huda Sukaraja sudah pernah mencoba untuk menggunakan beberapa metode dalam kegiatan pembelajaran, baik itu metode pembelajaran aktif, metode pembelajaran berbasis komputer dan termasuk metode-metode 
pembelajaran yang termasuk bagian dari model pembelajaran kelompok atau cooperative learning. Kegiatan pembelajaran menggunakan berbagai metode tersebut telah berjalan dengan baik meskipun tidak dapat terhindar dari berbagai masalah terlebih ketika dipadukan dengan kurikulum baru yaitu kurikulum 2013.

Hasil observasi menunjukkan bahwa permasalahan utama dihadapi pada pembelajaran khususnya mata pelajaran Fiqih di MA Nurul Huda Sukaraja adalah mengubah paradigma pembelajaran dari teacher centered learning menjadi student centered learning. Meskipun telah menerapkan kurikulum 2013 yang menekankan pada konsep student centered learning dan telah berupaya menerapkan metode pembelajaran berbasis aktivitas belajar peserta didik, namun pada praktek pembelajaran masih didominasi oleh pendidik. Selama kegiatan pembelajaran pendidik masih lebih banyak menggunakan waktu untuk memberikan penjelasan-penjelasan tentang materi pembelajaran secara lisan dengan cara ceramah. Selama kegiatan pembelajaran juga belum tampak aktivitas belajar peserta didik dalam melakukan pengamatan langsung terhadap materi pembelajaran, tidak terdapat aktivitas belajar peserta didik untuk mengumpulkan informasi terkait materi pembelajaran secara mandiri, dan kegiatan diskusi masih jarang dilaksanakan. Apabila guru melaksanakan kegiatan diskusi, proses pelaksanaan diskusi hanya dikuasai oleh beberapa orang peserta didik, sedangkan peserta didik lain masih bersikap pasif.

Pendidik selama kegiatan pembelajaran Fiqih di MA Nurul Huda Sukaraja masih lebih mendominasi aktivitas pembelajaran, sehingga pendidik adalah penyampai materi pelajaran yang berdiri di depan kelas, sedangkan peserta didik menjadi pendengar yang pasif. Keadaan pembelajaran Fiqih di MA Nurul Huda Sukaraja sebagaimana tersebut menjadikan pembelajaran belum dapat berjalan secara efektif. Hal tersebut tampak dari keadaan peserta didik selama kegiatan pembelajaran dimana mayoritas peserta didik tidak serius memperhatikan media pembelajaran yang ditampilkan pendidik terutama apabila pendidik menampilkan video pembelajaran. Selama penayangan video pembelajaran, keadaan peserta didik kurang dapat terkontrol yaitu terdapat peserta didik yang menertawakan isi video, berbicara dengan peserta didik lain, bahkan terdapat peserta didik yang tidak mengamati sama sekali video yang ditampilkan oleh pendidik.

Pembelajaran Fiqih di MA Nurul Huda Sukaraja juga tampak tidak efektif dilihat dari kemampuan peserta didik mengajukan pertanyaan maupun menjawab pertanyaan. Hal tersebut terlihat dari minimnya peserta didik yang dapat mengajukan pertanyaan maupun menjawab pertanyaan setelah tahap pengamatan. Selain itu, hanya terdapat beberapa orang peserta didik yang aktif dalam kegiatan diskusi sehingga tahap eksplorasi dan asosiasi tidak dapat berjalan secara maksimal. Sebagian peserta didik tampak bersikap acuh atau cuek dalam diskusi, bahkan banyak peserta didik yang tampak asik berbicara atau mengobrol bersama peserta didik lain. Terdapat juga peserta didik yang keluar masuk ruang kelas dengan alasan pergi ke toilet.

Keadaan pembelajaran Fiqih di MA Nurul Huda Sukaraja sebagaimana tersebut mengakibatkan pembelajaran tidak dapat berjalan secara efektif sehingga berpengaruh terhadap pemahaman peserta didik pada materi pembelajaran. Pemahaman peserta didik terhadap materi pembelajaran Fiqih di MA Nurul Huda Sukaraja tampak masih rendah yang hal tersebut dibuktikan dari hasil midle semester genap tahun pelajaran 2017/2018. Hasil midle semester genap pada mata pelajaran Fiqih di MA Nurul Huda Sukaraja menunjukkan dari 86 peserta didik kelas $\mathrm{X}$ hanya terdapat 37 peserta didik atau $43,02 \%$ yang dapat mencapai ketuntasan minimal yang telah ditetapkan, sedangkan 49 peserta didik atau $56,98 \%$ belum memperoleh nilai sesuai ketuntasan minimal yaitu memperoleh nilai $<75$.

Berbagai permasalahan pada pembelajaran Fiqih di MA Nurul Huda Sukaraja tersebut kemudian ditindaklanjuti dengan melakukan analisis penyebab masalah. Hasil analisis masalah menunjukkan bahwa permasalahan terletak pada penggunaan metode pembelajaran yang kurang efektif oleh pendidik. Oleh karena itu, peneliti bermaksud menawarkan satu metode untuk diterapkan yaitu metode Visualization, Auditory, Kinestetic (VAK). 
Berkaitan dengan metode Visualization, Auditory, Kinestetic (VAK), Madjid (2014:136) menjelaskan bahwa "Metode pembelajaran Visualization, Auditory, Kinestetic (VAK) adalah metode pembelajaran yang mengoptimalkan tiga modalitas belajar yaitu melihat, mendengarkan dan memahami nilai untuk menjadikan peserta didik merasa nyaman mengikuti kegiatan pembelajaran". Pengertian tersebut menunjukkan bahwa metode pembelajaran Visualization, Auditory, Kinestetic (VAK) merupakan suatu metode pembelajaran yang menganggap pembelajaran akan efektif dengan memperhatikan modalitas belajar yaitu Visual, Auditory, Kinestetic. Metode Visualization, Auditory, Kinestetic (VAK) memberikan kesempatan kepada peserta didik untuk belajar langsung dengan bebas menggunakan modalitas yang dimiliki.

Penjelasan tentang metode Visualization, Auditory, Kinestetic (VAK) memunculkan asumsi bahwa metode Visualization, Auditory, Kinestetic (VAK) akan efektif diterapkan pada pembelajaran Fiqih. Alasan pemilihan metode Visualization, Auditory, Kinestetic (VAK) adalah pembelajaran Fiqih tidak hanya sekedar take and give antara pendidik dan peserta didik tetapi lebih luas yakni peserta didik mempunyai kesempatan mengembangkan seluruh potensi yang dimiliki untuk dapat mengembangkan dan mempraktekkan materi pembelajaran dalam menyelesaikan berbagai permasalahan. Melalui metode Visualization, Auditory, Kinestetic (VAK) peserta didik dapat mengingat materi pembelajaran (Visual), mendengarkan (Auditory), dan mengembangkan emosi melalui implementasi langsung materi pembelajaran (Kinestetic).

Atas dasar hal tersebut, maka dilakukan penelitian berbentuk eksperimen untuk mengetahui pengaruh metode Visualization, Auditory, Kinestetic (VAK) terhadap hasil belajar mata pelajaran Fiqih.

\section{Metode Visualization, Auditory, Kinestetic (VAK)}

Metode pembelajaran Visual Auditory Kinestetic (VAK) merupakan metode pembelajaran yang menekankan bahwa belajar harus dilaksanakan dengan memanfaatkan alat indra dimiliki peserta didik. Menurut Nurhasanah (2010:122), "Metode pembelajaran Visual Auditory Kinestetic adalah suatu pembelajaran yang memanfaatkan gaya belajar setiap individu dengan tujuan agar semua kebiasaan belajar peserta didik akan terpenuhi". Gaya belajar setiap individu peserta didik dimaksudkan adalah gaya belajar visual atau melihat, auditory atau mendengarkan, dan kinestetic atau keterlibatan emosi melalui berbagi gerakan.

Secara lebih jelas dan terperinci Sugiyanto (2008:101) memberikan pengertian metode Visual, Auditory, dan Kinestetic (VAK) dengan mengemukakan:

Metode pembelajaran Visual Auditory Kinestetic adalah metode pembelajaran yang mengkombinasikan ketiga gaya belajar yaitu visual atau melihat, auditory mendengarkan, dan kinestetic atau keterlibatan emosi melalui berbagi gerakan setiap individu dengan cara memanfaatkan potensi yang telah dimiliki dengan melatih kemudian mengembangkannya, agar semua kebiasaan belajar peserta didik terpenuhi.

Setiap metode pembelajaran dilaksanakan berdasarkan langkah-langkah atau prosedur tertentu. Demikian halnya metode Visualization, Auditory, Kinestetic diimplementasikan berdasarkan berbagai prosedur yang harus diikuti. Prosedur pembelajaran merupakan pedoman dalam pelaksanaan pembelajaran menggunakan metode tertentu. Prosedur atau langkah-langkah penerapan metode Visualization, Auditory, Kinestetic didasarkan pada perbedaan modalitas belajar peserta didik. Ngalimun (2012:76) menyebutkan langkah-langkah dalam pembelajaran menggunakan metode Visualization, Auditory, Kinestetic berikut:

1. Tahap persiapan (kegiatan pendahuluan) yaitu pendidik memberikan motivasi untuk membangkitkan minat peserta didik dalam belajar, memberikan perasaan positif mengenai pengalaman belajar yang akan datang kepada peserta didik, dan menempatkan peserta didik dalam situasi optimal untuk menjadikan peserta didik lebih siap dalam menerima pelajaran.

2. Tahap penyampaian (kegiatan inti pada eksplorasi) yaitu pendidik mengarahkan peserta didik untuk menemukan materi pelajaran yang baru secara mandiri, 
menyenangkan, relevan, melibatkan pancaindera, yang sesuai dengan gaya belajar VAK.

3. Tahap pelatihan (kegiatan inti pada elaborasi) yaitu pendidik membantu peserta didik untuk mengintegrasi dan menyerap pengetahuan serta keterampilan baru dengan berbagai cara yang disesuaikan dengan gaya belajar VAK.

4. Tahap penampilan hasil (kegiatan inti pada konfirmasi) yaitu pendidik membantu peserta didik dalam menerapkan dan memperluas pengetahuan maupun keterampilan baru yang peserta didik dapatkan, pada kegiatan belajar sehingga hasil belajar mengalami peningkatan.

Berdasarkan penjelasan tentang metode Visualization, Auditory, Kinestetic dapat disimpulkan bahwa metode Visualization, Auditory, Kinestetic adalah metode pembelajaran yang mengkombinasikan ketiga gaya belajar yaitu melihat, mendengar, dan bergerak setiap individu dengan cara memanfaatkan potensi yang telah dimiliki dengan melatih dan mengembangkannya. Pembelajaran dengan metode Visualization, Auditory, Kinestetic mementingkan pengalaman belajar secara langsung dan menyenangkan bagi peserta didik. Pengalaman belajar secara langsung dengan cara belajar dengan mengingat (Visual), belajar dengan mendengar (Auditory), dan belajar dengan gerak dan emosi (Kinestetic)

\section{Hasil Belajar Fiqih}

Hasil merupakan hasil dicapai seseorang ketika mengerjakan tugas atau kegiatan tertentu. Hal tersebut sebagaimana dijelaskan Amri (2010:52) bahwa, "Hasil belajar adalah pencapaian peserta didik setelah melakukan proses belajar, baik di sekolah maupun di luar sekolah, baik secara individual maupun berkelompok". Pengertian tersebut menunjukkan bahwa hasil belajar merupakan hasil dicapai dari usaha belajar sebagaimana dinyatakan oleh skor nilai hasil evaluasi. Hasil belajar dijadikan sebagai suatu bukti keberhasilan belajar peserta didik melakukan kegiatan belajar sesuai bobot pencapaian kompetensi belajar.

Secara lebih jelas Djamarah (2010:136) mengemukakan bahwa, "Hasil belajar adalah perubahan yang terjadi pada peserta didik sebagai suatu bimbingan guru untuk mencapai tujuan yang ditetapkan dan dinyatakan dalam bentuk angka, huruf maupun simbol lain". Pengertian tersebut menunjukkan bahwa hasil belajar merupakan tingkat pencapaian peserta didik menerima, menolak serta menilai informasi-informasi pada proses pembelajaran. Prestasi belajar seseorang sesuai tingkat keberhasilan mempelajari materi pelajaran kemudian dinyatakan dalam bentuk nilai setiap bidang studi. Oleh karena itu, hasil belajar peserta didik dapat diketahui setelah diadakan evaluasi.

Hasil belajar Fiqih merupakan tingkat pemahaman peserta didik terhadap materi-materi pembelajaran pada mata pelajaran Fiqih. Hasil belajar Fiqih bukan hanya bersifat teoretis namun lebih bersifat praktis atau pengamalan. Oleh karena itu, hasil belajar Fiqih adalah tingkat ketercapaian tujuan pembelajaran Fiqih yang ditunjukkan oleh tingkat pemahaman serta pengamalan peserta didik terhadap materi pembelajaran dalam kehidupan sehari-hari.

Berdasarkan penjelasan hasil belajar Fiqih dapat disimpulkan bahwa hasil belajar Fiqih adalah tingkat kecakapan dan keberhasilan yang telah dicapai oleh peserta didik pada mata pelajaran Fiqih yang diperoleh dari pengalaman dan pengetahuan yang diikuti peserta didik melalui proses belajar di sekolah. Hasil belajar Fiqih termanifestasikan dalam nilai hasil evaluasi pada mata pelajaran Fiqih. Oleh karena itu hasil belajar Fiqih adalah skor nilai yang diperoleh peserta didik setelah mengikuti serangkaian tes yang diberikan.

\section{METODE/EKSPERIMEN}

Berdasarkan jenis data serta teknik analisis data yang digunakan, penelitian ini termasuk penelitian kuantitatif. Sudjana (2010:18) mengemukakan, "Penelitian kuantitatif adalah penelitian menggunakan data kuantitatif atau data berbentuk angka". Berdasarkan tingkat eksplanasi jenis 
penelitian yang digunakan adalah penelitian eksperimen. Sugiyono (2009:6) menjelaskan, "Penelitian eksperimen merupakan metode penelitian yang digunakan untuk mencari pengaruh treatment atau perlakuan tertentu seperti pengaruh ruang kerja terhadap produktivitas kerja". Desain penelitian digunakan pada penelitian ini adalah eksperimen perbandingan perlakuan tanpa ada pretest atau Postest Control Group Design.

Variabel penelitian ini terdiri dari variabel bebas (dependent) dan variabel terikat (independent). Variabel terikat adalah variabel terpengaruh atau variabel akibat. Variabel bebas dalam penelitian ini adalah metode Visualization, Auditory, Kinestetic (VAK), sedangkan variabel terikat penelitian ini adalah hasil belajar mata pelajaran Fiqih peserta didik kelas X MA Nurul Huda Sukaraja. Besar pengaruh variabel terikat terhadap variabel kontrol diketahui dengan cara analisis statistik menggunakan uji t. Populasi dalam penelitian ini adalah peserta didik kelas X MA Nurul Huda Sukaraja Tahun Pelajaran 2018/2019 berjumlah 86 peserta didik dan terbagi dalam 3 kelas. Sampel penelitian berjumlah 56 peserta didik yang terbagi dalam dua kelas.

Data pada penelitian ini adalah hasil belajar yang diketahui menggunakan tes. Tes disusun 25 nomor berbentuk pilihan ganda dengan 5 opsi jawaban yaitu a, b, c, d dan e. Jika peserta didik menjawab benar mendapatkan skor 1 dan jika salah mendapatkan skor 0 , skor maksimal yang dapat diperoleh peserta didik adalah 25 . Uji instrumen penelitian yang dilakukan adalah uji validitas, uji reliablitas, uji tingkat kesukaran, dan uji daya pembeda soal. Prasyarat analisis data yang dilakukan meliputi uji normalitas dan uji homogenitas. Adapun uji hipotesis yang digunakan adalah uji $t$ polled varian adatau sampel berpasangan. Alasan penggunaan uji $t$ polled varian adalah jumlah $n_{1} \neq n_{2}$, data pada penelitian ini berdistribusi normal, serta varian data ( $\sigma 2)$ diketahui (Sugiyono, 2013:197). Pengujian hipotesis menggunakan uji $t$ polled varian dilakukan menggunakan persamaan:

$$
t=\frac{\bar{X}_{1}-\bar{X}_{2}}{\sqrt{\frac{\left(n_{1}-1\right) S_{1}^{2}+\left(n_{2}-1\right) S_{2}^{2}}{n_{1}+n_{2}-2}\left(\frac{1}{n_{1}}+\frac{1}{n_{2}}\right)}}
$$

\section{HASIL DAN PEMBAHASAN}

Penelitian ini bertujuan untuk mengetahui ada tidaknya pengaruh yang signifikan penerapan metode Visualization, Auditory, Kinestetic (VAK) terhadap hasil belajar Fiqih materi Tatacara Pengurusan Jenazah peserta didik kelas X MA Nurul Huda Sukaraja Kecamatan Buay Madang. Untuk mengetahui ada atau tidak pengaruh metode Visualization, Auditory, Kinestetic (VAK) terhadap hasil belajar mata pelajaran Fiqih materi pembelajaran Tatacara Pengurusan Jenazah peserta didik kelas X MA Nurul Huda Sukaraja digunakan instrumen tes. Tes dilaksanakan secara tertulis dengan 25 nomor soal-soal pilihan ganda. Sebelum instrumen tes digunakan terlebih dahulu dilakukan uji instrumen baik uji validitas, uji reliabilitas, tingkat kesukaran soal dan daya pembeda soal. Hasil tes menunjukkan dari 25 soal terdapat 20 soal valid. Setelah dilakukan analisis data hasil tes pada kedua kelas penelitian, diperoleh hasil penelitian sebagai berikut:

\section{Hasil Belajar Fiqih Kelas Eksperimen}

Data hasil belajar Fiqih peserta didik kelas eksperimen yaitu peserta didik kelas X IPA MA Nurul Huda Sukaraja Kecamatan Buay madang diketahui menggunakan instrumen tes sebanyak 20 nomor yang telah memenuhi syarat uji instrumen penelitian. Tes diikuti oleh seluruh peserta didik yang berjumlah 27 orang peserta didik. Analisis hasil tes mata pelajaran Fiqih kelas eksperimen menunjukkan bahwa hasil belajar Fiqih materi pembelajaran Tatacara Pengurusan Jenazah peserta didik kelas eksperimen yang pembelajarannya menerapkan metode Visualization, Auditory, Kinestetic (VAK) adalah sedang. Hasil tes menunjukkan bahwa dari 27 orang peserta didik terdapat 7 peserta didik atau 25,93\% memperoleh nilai kategori tinggi, 19 orang peserta didik atau $70,37 \%$ memperoleh nilai kategori sedang, dan 1 orang peserta didik

Hasanudin $^{1}$ dan Muarif ${ }^{2}$ 
atau $3,70 \%$ memperoleh nilai kategori rendah. Perolehan nilai hasil tes sebagaimana tersebut menunjukkan bahwa mayoritas peserta didik memperoleh nilai kategori sedang. Persentase hasil belajar peserta didik dalam kategori sedang sebesar $70,37 \%$ telah lebih dari $50 \%$ sehingga dijadikan sebagai simpulan penelitian.

Hasil penelitian tersebut menunjukkan bahwa metode Visualization, Auditory, Kinestetic (VAK) efektif diterapkan pada pembelajaran Fiqih. Melalui penerapan metode Visualization, Auditory, Kinestetic (VAK) peserta didik dapat berperan aktif dalam mengikuti kegiatan pembelajaran dengan memanfaatkan tiga modalitas utama belajar. Hasil penelitian ini sejalan dengan pendapat Madjid (2014:136) yang menjelaskan bahwa "Metode pembelajaran Visualization, Auditory, Kinestetic (VAK) adalah metode pembelajaran yang mengoptimalkan tiga modalitas belajar yaitu melihat, mendengarkan dan memahami nilai untuk menjadikan peserta didik merasa nyaman mengikuti kegiatan pembelajaran". Pengertian tersebut menunjukkan bahwa metode pembelajaran Visualization, Auditory, Kinestetic (VAK) merupakan suatu metode pembelajaran yang menganggap pembelajaran akan efektif dengan memperhatikan modalitas belajar yaitu Visual, Auditory, Kinestetic. Metode Visualization, Auditory, Kinestetic (VAK) memberikan kesempatan kepada peserta didik untuk belajar langsung dengan bebas menggunakan modalitas yang dimiliki untuk mencapai pemahaman dan pembelajaran yang efektif.

\section{Hasil Belajar Fiqih Kelas Kontrol}

Hasil belajar Fiqih peserta didik kelas kontrol adalah hasil tes peserta didik yang pembelajarannya menerapkan metode ceramah plus penugasan. Hasil tes peserta didik diketahui menggunakan instrumen tes sebanyak 20 nomor yang telah memenuhi syarat uji instrumen penelitian. Tes diikuti oleh seluruh peserta didik kelas kontrol yaitu kelas X MAK MA Nurul Huda Sukaraja yang berjumlah 29 peserta didik. Analisis hasil tes mata pelajaran Fiqih peserta didik kelas kontrol menunjukkan bahwa hasil belajar yang diraih peserta didik masuk dalam kategori sedang. Hasil tes menunjukkan dari 29 orang peserta didik hanya terdapat 1 peserta didik atau $3,45 \%$ yang memperoleh nilai kategori tinggi, 22 peserta didik atau $75,86 \%$ memperoleh nilai kategori sedang, dan 6 peserta didik atau 20,69\% memperoleh nilai kategori rendah. Oleh karena itu dapat disimpulkan bahwa hasil belajar Fiqih peserta didik kelas kontrol yang pembelajarannya menerapkan metode ceramah plus penugasan adalah sedang.

3. Hasil Uji Hipotesis Pengaruh Visualization, Auditory, Kinestetic (VAK) Terhadap Hasil Belajar Fiqih Peserta Didik

Analisis data hasil tes kedua kelas menunjukkan bahwa hasil belajar peserta didik pada mata pelajaran Fiqih materi Tatacara Pengurusan Jenazah kelas X MA Nurul Huda Sukaraja yang pembelajarannya menerapkan metode Visualization, Auditory, Kinestetic (VAK) lebih baik dari peserta didik yang pembelajarannya tanpa menerapkan metode Visualization, Auditory, Kinestetic (VAK) atau hanya menggunakan metode ceramah plus penugasan. Hal tersebut terbukti dari tabel persentase yang menunjukkan bahwa pada kelompok peserta didik yang pembelajarannya menerapkan metode Visualization, Auditory, Kinestetic (VAK) terdapat 7 peserta didik atau 25,93\% memperoleh nilai kategori tinggi dan hanya terdapat 1 peserta didik atau $3,45 \%$ memperoleh nilai kategori tinggi pada kelas menggunakan metode ceramah plus penugasan. Selain itu, pada kelas menggunakan metode Visualization, Auditory, Kinestetic (VAK) hanya terdapat 1 peserta didik atau 3,70\% memperoleh nilai ketegori rendah, sedangkan pada kelas menggunakan metode ceramah plus penugasan terdapat 6 peserta didik atau 20,69\% memperoleh nilai kategori rendah.

Setelah masing-masing data hasil tes dianalisis, langkah selanjutnya adalah melakukan uji hipotesis menggunakan uji $t$ polled varian. Berdasarkan hasil uji $t$ polled varian diperoleh harga $t_{\text {hitung }}$ sebesar $=5,45$. Angka tersebut kemudian dikonsultasikan dengan nilai $t_{\text {tabel }}$ dengan taraf kepercayaan $95 \%$ dan probabilitas kesalahan sebesar 0,05 dengan $\mathrm{db}=\left(\mathrm{N}_{1}+\mathrm{N}_{2}-2\right)=27+29-$ 
$2=54$. Oleh karena pada tabel $t$ tidak diketemukan db 54, maka dilakukan perhitungan menggunakan interpolasi. Berdasarkan perhitungan interpolasi di atas diketahui bahwa nilai $t_{\text {tabel }}$ untuk df $27+29-2=54$ adalah 1,99 . Kriteria pengujian hipotesis penelitian ini adalah terima $\mathrm{H}_{0}$ apabila $-t_{\text {tabel }} \leq t_{\text {hitung }}<+t_{\text {tabel }}$ dan tolak $H_{0}$ dalam hal lainnya. Oleh karena $t_{\text {hitung }} 5,45$ tidak terletak diantara $-\mathrm{t}_{\text {tabel }} \leq \mathrm{t}_{\text {hitung }}<+\mathrm{t}_{\text {tabel }}$ yaitu $-1,99$ dan $+1,99$ maka $\mathrm{H}_{\mathrm{o}}$ yang menyatakan tidak terdapat pengaruh yang signifikan penerapan metode Visualization, Auditory, Kinestetic (VAK) terhadap hasil belajar Fiqih materi Tatacara Pengurusan Jenazah peserta didik kelas X MA Nurul Huda Sukaraja Kecamatan Buay Madang ditolak, sedangkan $\mathrm{H}_{\mathrm{a}}$ yang menyatakan terdapat pengaruh yang signifikan penerapan metode Visualization, Auditory, Kinestetic (VAK) terhadap hasil belajar Fiqih materi Tatacara Pengurusan Jenazah peserta didik kelas X MA Nurul Huda Sukaraja Kecamatan Buay Madang diterima.

Hasil analisis data menunjukkan secara nyata terdapat pengaruh penerapan metode Visualization, Auditory, Kinestetic (VAK) terhadap hasil peserta didik pada materi pembelajaran Tatacara Pengurusan Jenazah di kelas X MA Nurul Huda Sukaraja. Peserta didik yang pembelajarannya menerapkan metode Visualization, Auditory, Kinestetic (VAK) memiliki hasil belajar yang lebih tinggi dibandingkan dengan peserta didik yang pembelajarannya tanpa menerapkan metode Visualization, Auditory, Kinestetic atau hanya menggunakan metode ceramah plus penugasan. Hal tersebut terbukti dari tabel persentase bahwa pada kelompok peserta didik yang pembelajarannya menggunakan metode Visualization, Auditory, Kinestetic (VAK) terdapat 7 peserta didik atau 25,93\% memperoleh nilai kategori tinggi dan hanya terdapat 1 peserta didik atau $3,45 \%$ memperoleh nilai kategori tinggi pada kelas menggunakan metode ceramah plus penugasan. Selain itu, pada kelas menggunakan metode Visualization, Auditory, Kinestetic (VAK) hanya terdapat 1 peserta didik atau 3,70\% memperoleh nilai ketegori rendah, sedangkan pada kelas menggunakan metode ceramah plus penugasan terdapat 6 peserta didik atau $20,69 \%$ memperoleh nilai kategori rendah. Untuk lebih jelasnya presentase hasil belajar peserta didik pada materi pembelajaran Tatacara Pengurusan Jenazah di kelas X MA Nurul Huda Sukaraja kedua kelas pada tiap kategori dapat dilihat pada diagram berikut:

Persentase Hasil Belajar Peserta Didik Kelas Eksperimen dan Kelas Kontrol

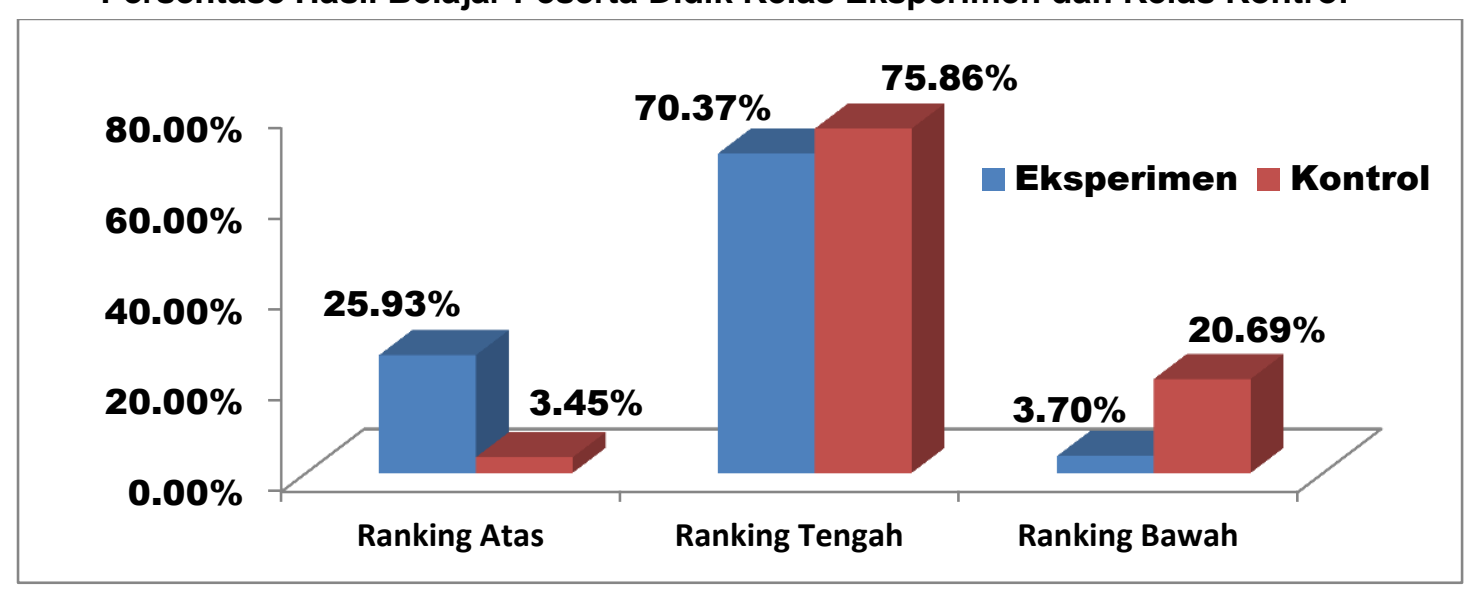

Diagram menunjukkan hasil belajar mata pelajaran Fiqih materi Tatacara Pengurusan Jenazah peserta didik yang pembelajarannya menerapkan metode Visualization, Auditory, Kinestetic (VAK) lebih baik dari peserta didik yang pembelajarannya menerapkan metode ceramah plus penugasan. Data hasil penelitian menunjukkan bahwa metode Visualization, Auditory, Kinestetic (VAK) efektif untuk digunakan atau diterapkan pada pembelajaran Fiqih materi pembelajaran Tatacara Pengurusan Jenazah. Hasil penelitian menunjukkan bahwa selama kegiatan pembelajaran kelebihan metode Visualization, Auditory, Kinestetic (VAK) adalah dapat menciptakan proses belajar yang lebih bermakna, dimana peserta didik mengalami apa yang mereka pelajari. Melalui metode ini, peserta didik belajar tidak hanya belajar tentang konsep materi belaka, hal ini dikarenakan peserta didik dilibatkan secara langsung dalam proses 
pembelajaran untuk dijadikan sebagai suatu pengalaman. Hasil dari proses pembelajaran metode Visualization, Auditory, Kinestetic (VAK) tidak hanya menekankan pada aspek kognitif saja, juga tidak seperti teori behavior yang menghilangkan peran pengalaman subjektif dalam proses belajar. Pengetahuan yang tercipta dari model ini merupakan perpaduan antara memahami dan mentransformasi pengalaman.

Penerapan metode Visualization, Auditory, Kinestetic (VAK) menuntut peserta didik untuk aktif mengikuti seluruh kegiatan pembelajaran. Metode Visualization, Auditory, Kinestetic (VAK) akan memberikan berbagai kemudahan bagi peserta didik untuk memahami materi pembelajaran sehingga peserta didik memiliki bahan cukup untuk memperdalam pemahamannya terhadap materi pembelajaran. Penggunaan metode Visualization, Auditory, Kinestetic (VAK) dapat mendalami materi pembelajaran, memahami prosedur pemahaman materi pembelajaran, mengetahui materi pembelajaran akan datang, melatih menyelesaikan persoalan yang akhirnya mempermudah peserta didik meraih hasil belajar secara maksimal.

\section{PENUTUP}

Berdasarkan analisis dan pembahasan hasil penelitian yang telah dilaksanakan dapat disimpulkan sebagai berikut:

1. Hasil I belajar Fiqih materi Tatacara Pengurusan Jenazah peserta didik yang pembelajarannya menerapkan metode Visualization, Auditory, Kinestetic (VAK) di kelas X MA Nurul Huda Sukaraja Kecamatan Buay Madang adalah sedang yaitu dari 27 orang peserta didik terdapat 7 peserta didik atau 25,93\% memperoleh nilai kategori tinggi, 19 orang peserta didik atau $70,37 \%$ memperoleh nilai kategori sedang, 1 orang peserta didik atau 3,70\% memperoleh nilai kategori rendah dengan nilai rata-rata 78,06.

2. Hasil belajar Fiqih materi Tatacara Pengurusan Jenazah peserta didik yang pembelajarannya menerapkan metode ceramah di kelas X MA Nurul Huda Sukaraja Kecamatan Buay Madang adalah sedang yaitu dari 29 orang peserta didik hanya terdapat 1 peserta didik atau 3,45\% yang memperoleh nilai kategori tinggi, 22 peserta didik atau 75,86\% memperoleh nilai kategori sedang, dan 6 peserta didik atau 20,69\% memperoleh nilai kategori rendah dengan nilai rata-rata 66,78.

3. Terdapat pengaruh yang signifikan penerapan metode Visualization, Auditory, Kinestetic (VAK) terhadap hasil belajar Fiqih materi Tatacara Pengurusan Jenazah peserta didik kelas X MA Nurul Huda Sukaraja Kecamatan Buay Madang dengan harga $t_{\text {hitung }}$ sebesar $=5,45$ sedangkan nilai $t_{\text {tabel }}$ dengan taraf signifikansi $95 \%$ atau 0,05 pada uji dua pihak yaitu 1,99 . Karena $t_{\text {hitung }} 5,45$ tidak terletak diantara $-t_{\text {tabel }} \leq t_{\text {hitung }}<+t_{\text {tabel }}$ yaitu $-1,99$ dan $+1,99$ maka $H_{\circ}$ ditolak, sedangkan $H_{a}$ diterima.

Berdasarkan hasil penelitian yang menunjukkan adanya pengaruh yang signifikan penerapan metode Visualization, Auditory, Kinestetic (VAK) terhadap hasil belajar Fiqih materi Tatacara Pengurusan Jenazah peserta didik kelas X MA Nurul Huda Sukaraja Kecamatan Buay Madang, maka dapat disarankan:

1. Guru hendaknya dapat menerapkan metode Visualization, Auditory, Kinestetic (VAK) pada pembelajaran Fiqih secara efektif sesuai dengan tingkat perkembangan dan kemampuan peserta didik agar materi pembelajaran dapat benar-benar tersampaikan kepada peserta didik dan tujuan pembelajaran dapat tercapai dengan baik. Guru dalam melaksanakan pembelajaran Fiqih menggunakan metode Visualization, Auditory, Kinestetic (VAK) hendaknya dapat memilih dan memberikan berbagai signal sesuai tingkat perkembangan peserta didik sehingga peserta didik dapat merespon stimulus yang diberikan dengan baik.

2. Peserta didik dalam mengikuti kegiatan pembelajaran Fiqih menggunakan metode Visualization, Auditory, Kinestetic (VAK) hendaknya lebih aktif dan kreatif merespon berbagai stimulus yang diberikan guru agar dapat memahami materi pembelajaran dengan baik dan meraih hasil belajar 
secara maksimal. Apabila guru mempergunakan model pembelajaran konvensional seperti ceramah plus penugasan hendaknya peserta didik dapat mengambil inisiatif untuk lebih memahami materi pembelajaran seperti belajar secara mandiri, mencari informasi, berdiskusi di luar jam pelajaran maupun kegiatan lainnya agar dapat menambah wawasan serta pengetahuan peserta didik terhadap materi pembelajaran

3. Sekolah hendaknya dapat memberikan pelayanan pada kegiatan pembelajaran menggunakan metode Visualization, Auditory, Kinestetic (VAK) dengan menyediakan berbagai sarana penunjang agar kegiatan pembelajaran dapat berjalan dengan baik. Sekolah hendaknya dapat memacu berbagai kegiatan eksperimen pada semua mata pelajaran dan mengembangkan berbagai metode pembelajaran berbasis aktivitas belajar peserta didik.

\section{UCAPAN TERIMAKASIH}

Peneliti mengucapkan terima kasih kepada STKIP Nurul Huda Sukaraja Buay Madang OKU Timur, MA Nurul Huda Sukaraja Kecamatan Buay Madang, dan LPPM STKIP Nurul Huda yang telah memberikan kontribusi dalam penelitian ini.

\section{DAFTAR PUSTAKA}

Amri, Abu dan Suprijono. 2010. Psikologi Pendidikan. Jakarta: Rineka Cipta.

Djamarah, Syaiful Bahri. 2010. Strategi Belajar Mengajar. Jakarta: Rineka Cipta.

Kemendikbud. 2016. Kurikulum Pembelajaran Fiqih Kurikulum 2013 Edisi 2016. Jakarta: Kemendikbud.

Madjid, Abdul. 2014. Model-model Pembelajaran. Bandung: Alfabeta.

Ngalimun, 2012. Strategi dan Model Pembelajaran.Yogyakarta: Aswaja Pressindo.

Nurhasanah. 2010. Tipe-tipe Pembelajaran Invotif Kreatif. Semarang: Media Pustaka.

Sudjana. 2010. Metoda Statistika. Bandung: Tarsito.

Sugiyanto. 2008. Model dan Metode Pembelajaran Kooperatif. Jakarta: Praya Media.

Sugiyono. 2009. Metodologi Penelitian Kualitatif, Kuantitatif, dan R\&B. Bandung: Alfabeta.

Sugiyono. 2013. Dasar-dasar Statistik Pendidikan. Bandung: Alfabeta. 